J. Product. \& Dev., 17(1):105- 125(2012)

\title{
RESPONSE OF GROWING RABBITS TO DIETS CONTAINING DIFFERENT LEVELS OF WHEAT SCREENING BY-PRODUCT WITH OR WITHOUT ENZYME SUPPLEMENTATION
}

\author{
I. M. Abaza and M.E. Omara* \\ Poultry Nutrition Research Department, Animal Production Research \\ Institute, Agriculture Research Center, Giza, Egypt. \\ *Waterfowl and rabbit breeding Research Department, Animal Production \\ Research Institute, Agriculture Research Center, Giza, Egypt.
}

\section{ABSTRACT:}

A total number of one hundred weanling New Zealand White rabbits aged five weeks were used in this study. Rabbits were randomly distributed into ten experimental treatments; each one contains 5 males and 5 females in individual cages. Five levels (0, 5, 10, 15 and $20 \%)$ of wheat screening by-product (WSP) and each level was fed without or with addition of enzyme preparation in $5 \times 2$ factorial design arrangement. Enzyme preparation ( containing $\beta$-Xylanase and $\alpha$-Amylase) was added at 0 and $500 \mathrm{~g} /$ ton of diets, during the experimental period from 5 to 12 weeks of age.

The obtained results could be summarized as follows: The rabbits fed diet containing 5\% WSP with enzymes significantly recorded the highest values of body weight, body weight gain and relative growth rate followed by those fed diet containing 10\% WSP with enzyme addition. The rabbits fed diet containing 20\% WSP without enzymes recorded the lowest significant values in these respects. The rabbits fed diet containing $20 \%$ WSP with enzymes consumed the highest amount of feed compared with those for other groups. The best feed conversion ratio was recorded for rabbits fed diet containing 5\% WSP with enzymes additions followed by those for control, 10 and 15\% WSP with enzymes addition compared with all other dietary treatments. Enzymes supplementation in diets containing WSP significantly improved the digestibility coefficients of nutrients and carcass traits of rabbits compared with other groups. Total protein, cholesterol and urea were significantly decreased by increasing the level of WSP in the experimental diets. However, the differences between rabbits fed diets containing different levels of WSP with or without enzymes addition and the control diet in albumin and globulin was not significant. Rabbits fed diets containing different levels of WSP and provided with enzymes recorded significantly the lowest values of cholesterol compared with those fed the diets containing WSP without enzymes and control diet. 
The addition of enzymes in diets containing WSP significantly improved the liver functions. Chemical composition of meat did not significantly differ with the WSP and enzymes addition. Results showed an improvement in average values of net revenue, economical efficiency and relative economical efficiency due to feeding growing rabbits on diet containing $5 \%$ WSP with enzyme preparation.

In conclusion, use of the WSP can be successfully fed at level $5 \%$ of growing rabbit diets with enzymes supplementation ( $\beta$-xylanase; $\alpha$ amylase) without any adverse effect on growth performance and economical efficiency, under Egyptian conditions.

Keywords: Wheat screening; digestibility; $\beta$-xylanase; $\alpha$-amylase; rabbits.

\section{INTRODUCTION}

Wheat screening by-product (WSP) is a fine by-product produced when the grains stored at the tower silos are cleaned by vacuum screening. Because of its high fiber content, it might be a useful feed ingredient in animal diets. In the light of these statements, when corn and barley are expensive or unavailable, WSP can replace their in animal feeding. In addition, WSP is available in reasonable quantities in Egypt from wheat storage silos. It is well known now that the nutritive value of WSP is adversely affected by the presence of certain non-starch polysaccharides (NSP) in its endosperm cell walls. An important feature of the NSP is the mixed linked arabinoxylan and glucan.

Using enzymes is well documented across different types of monogastric animal diets for different purposes such as keeping the gut healthy (Ferket, 2011), improving the utilization of nutrients (Selim et al., 2009), improving the performance of intestine and elevating the nutritive value of the diets (Bedford and Morgan, 1996 and Tawfeek, 1996). The addition of dietary enzymes preparation could be largely attributed to the degradation of the viscosity of intestinal digesta Sullivan (1987) and Easter (1988) in diets which contain high level of NSP. It has been shown that the anti-nutritional activity of arabinoxylans in monogastric animal is not a function of the polymers, but of the intestinal viscosity that they create, it may be concluded that the nutritional and, therefore, economic value of barley, oats, rye and even wheat can be improved by the addition of the appropriate preparation of xylanase and $\beta$ glucanase enzymes (Campbell and Bedford, 1992; Chesson, 1993 and Walsh et al., 1993). Dietary enzymes preparation product contains xylanase reduces viscosity and breaks down cereal cell walls (Cowieson et al., 2005), amylase improves starch utilization (Jiang et al., 2008 and (Pérez-Vendrell et al., 2009) may be effective in improving energy utilization in corn-soy diets Michael 
(2002). Endoxylanase degrades the xylan (backbone of arabinoxylan) into smaller units (xylose), which have several beneficial consequences and are more available to monogastrics (Odetallah 2000).

The aim of the present study was to evaluate the effect of using wheat screening by-product (WSP) at levels of $0,5,10,15$ and $20 \%$ and each level was fed without or with enzyme preparation ( $\beta$-Xylanase and $\alpha$-Amylase) in experimental diets on growth performance, digestibility of nutrients, carcass traits, some blood constituents, composition of meat and economic efficiency of NZW rabbits, under Egyptian conditions.

\section{MATERIALS AND METHODS}

The present study was carried out at Sakha Animal Production Research Station, Animal Production Research Institute, Agriculture Research Center, Egypt, from April to June, 2010. The wheat screening by-product (WSP) used in this study was kindly taken from silo in Kafr El Sheikh Government.

\section{Rabbits}

A total number of one hundred weanling New Zealand White (NZW) rabbits of five weeks of age were assigned at random to ten groups ( 5 males and 5 females) per each. The individual rabbit was allocated in a cage with slatted floor of iron $(45 \times 45 \times 38 \mathrm{~cm})$ for length, width and height, respectively. Water and feed were offered to the rabbits ad-libitum, during the experimental period (5 to 12 weeks of age).

\section{Experimental diets}

The ten experimental treatments were arranged as $5 \times 2$ factorial design with five levels $(0,5,10,15$ and $20 \%)$ of wheat screening by-product (WSP) and each level was fed without or with enzyme preparation $(\beta$-Xylanase and $\alpha$ Amylase) in the experimental diets. A commercial enzyme preparation "Xylam as product of Nutrex Co. Belgium." was added at 0 and $500 \mathrm{~g} /$ ton of the experimental diet. Each gram of Xylam contained 1260 IU 1-4 $\beta$-Xylanase and 8000 IU $\alpha$-Amylase.

Accordingly, there were 10 experimental diets (D) as follows: D1: containing $0 \%$ WSP without enzyme preparation (control diet), D2: containing $0 \%$ WSP with enzyme preparation, D3: containing $5 \%$ WSP without enzyme preparation, D4: containing 5\% WSP with enzyme preparation, D5: containing $10 \%$ WSP without enzyme preparation, D6: containing $10 \%$ WSP with enzyme preparation, D7: containing $15 \%$ WSP without enzyme preparation, D8: containing $15 \%$ WSP with enzyme 
preparation. D9: containing $20 \%$ WSP without enzyme preparation, D10: containing 20\% WSP with enzyme preparation.

All diets were nearly iso- nitrogenous of about $16.5 \%$ crude protein, iso- caloric of about $2410 \mathrm{Kcal} \mathrm{DE}$. All experimental pelleted diets were formulated as recommended by the National Research Council (NRC, 1994). The formulation and chemical composition of experimental diets D1, D3, D5, D7 and D9 are shown in Table 1.

\section{Measurements and determinations}

Live body weight (BW) and daily feed intake (DFI) were recorded for rabbits biweekly and daily body weight gain (DBG), relative growth rate (RGR), feed conversion (FC) (feed, g/gain, g) values and viability rate were calculated at the end of the feeding trial.

At the end of the growth performance experiment, four males rabbits from each treatment were housed individually and used in the digestibility experiment. The collection period lasted for 5 days. Feed intake was measured and feces output was collected daily. Hair and scattered feed were separated or taken out of the feces. The collected feces of each treatment was pooled together, and then dried at $60^{\circ} \mathrm{C}$ till constant weight. The dried feces for the successive five days was left few hours to get equilibrium with it in the atmosphere then, ground, well mixed and stored in screw-top glass jars for analysis. At the end of the experiment (12 weeks of age), four rabbits from each treatment were fasted for 12 hours, weighed and slaughtered to estimate some of carcass and blood constituents.

Blood samples were taken from each rabbits during slaughter to determine total protein, albumin and total cholesterol which determined according to Gornal et al. (1949), Doumas (1971) and Zollner, and Kirsch (1962), respectively. The total globulin values were calculated by subtracting the values of total albumin from the values of total protein for each sample. Aspartate aminotransferase (AST), alanine aminotransferase (ALT) and urea were determined by kits from Bio-Merieux (France) according to the procedure outlined by the manufacturer.

The chemical composition of WSP, diets, feces and meat for percentages of dry matter $(\mathrm{DM})$, organic matter $(\mathrm{OM})$, crude protein $(\mathrm{CP})$, crude fiber $(\mathrm{CF})$, ether extract (EE), nitrogen free extract (NFE) and ash were conducted according to AOAC (2000). Digestible energy (DE) of WSP was calculated according to Fonnesbeck et al. (1974) as follows:

$\mathrm{DE}(\mathrm{Kcal} / \mathrm{g}$ diet $)=4.36-0.0491(\mathrm{NDF} \%)$, Neutral detergent fiber (NDF) was calculated according to Pagano Toscano et al. (1986) as follows: $\mathrm{NDF} \%=28.924+0.657$ (CF\% on DM basis). 
Table 1: Formulation and chemical composition of the experimental diets.

\begin{tabular}{|c|c|c|c|c|c|}
\hline \multirow{2}{*}{ Ingredients } & \multicolumn{5}{|c|}{ Experimental diets } \\
\hline & D1 & D3 & D5 & D7 & D9 \\
\hline $\mathrm{WSP}^{1}$ & - & 5.0 & 10.0 & 15.0 & 20.0 \\
\hline Yellow corn & 20.0 & 15.0 & 10.0 & 5.0 & - \\
\hline Soybean meal $44 \%$ & 17.30 & 17.0 & 17.1 & 17.7 & 18.0 \\
\hline Alfalfa dehydrate $12 \%$ & 28.85 & 25.69 & 22.39 & 20.39 & 18.80 \\
\hline Barley & 15.53 & 18.13 & 22.63 & 30.03 & 36.33 \\
\hline Wheat bran & 12.0 & 13.3 & 12.0 & 6.0 & 1.0 \\
\hline Molasses & 2.7 & 2.7 & 2.7 & 2.7 & 2.7 \\
\hline Di calcuim Phosphate & 2.4 & 2.4 & 2.4 & 2.4 & 2.4 \\
\hline Limestone & 0.55 & 0.11 & 0.11 & 0.11 & 0.10 \\
\hline DL-Methionine & 0.07 & 0.07 & 0.07 & 0.07 & 0.07 \\
\hline Vit. and Min. premix ${ }^{2}$ & 0.3 & 0.3 & 0.3 & 0.3 & 0.3 \\
\hline$\underline{\text { Salt }(\mathrm{NaCl})}$ & $\underline{0.3}$ & $\underline{0.3}$ & $\underline{0.3}$ & $\underline{0.3}$ & $\underline{0.3}$ \\
\hline Total & $\overline{100}$ & $\overline{100}$ & $\overline{100}$ & $\overline{100}$ & $\overline{100}$ \\
\hline \multicolumn{6}{|c|}{ Calculated chemical analysis ${ }^{3}(\%)$} \\
\hline Crud protein ( C.P ) \% & 16.58 & 16.57 & 16.56 & 16.57 & 16.51 \\
\hline Ether extract (E.E) \% & 2.42 & 2.33 & 2.18 & 1.93 & 1.7 \\
\hline Crude fiber ( C.F ) \% & 12.45 & 12.27 & 12.30 & 12.18 & 12.21 \\
\hline Calcium \% & 1.28 & 1.08 & 1.04 & 1.01 & 1.00 \\
\hline Available Phosphorus, \% & 0.56 & 0.55 & 0.54 & 0.53 & 0.52 \\
\hline Methionin, $\%$ & 0.32 & 0.33 & 0.33 & 0.33 & 0.33 \\
\hline Lysin, \% & 0.86 & 0.86 & 0.87 & 0.89 & 0.89 \\
\hline Digestible energy $(\mathrm{kcal} / \mathrm{kg})^{4}$ & 2412.6 & 2413.4 & 2411.4 & 2410.8 & 2404.9 \\
\hline Price per $100 \mathrm{~kg}(\mathrm{~L} . \mathrm{E})^{5}$ & 162.56 & 163.10 & 163.20 & 161.76 & 159.60 \\
\hline
\end{tabular}

1 - WSP $=$ Wheat screening by-product

2- Each 3 kg vitamin and mineral premix provides: Vit. A 12000000 IU, Vit. D3 750000 IU, Vit. E 10000 mg, Vit. K 2000 mg, Vit. B 1000 mg, Vit. B 4000 mg, Vit. B 61500 mg, Vit. $B_{12} 10 \mathrm{mg}$, Pantothenic Acid $10000 \mathrm{mg}$,Niacin $20000 \mathrm{mg}$, Biotine $50 \mathrm{mg}$, Folic Acide 1000 $\mathrm{mg}$,Choline choloride 500mg, selenium 100mg, Manganese $55 \mathrm{gm}$, Zinc $50 \mathrm{gm}$, Fe $60 \mathrm{gm}$, $\mathrm{CU} 2.5 \mathrm{gm}, \mathrm{CO} 6 \mathrm{mg}$ and Iodine $1 \mathrm{gm}$.

3-According to Feed Composition Tables for animal and poultry feedstuffs used in Egypt (2001), except the values of WSP which were determined Table 2.

4-Calculated according to Fonnesbeck et al. (1974)

5- According to prices of the used ingredients at the experimental time (2010).

Economical efficiency (EEF)

Economical efficiency (EEF) of the experimental diets were calculated from the input/output analysis according to the price of the experimental diets and live body weight. Values of E.E.F were calculated according to the following equation.

$$
\text { E.E.F }=\text { A } / \mathrm{B} \times 100 \quad \mathrm{~A}=\mathrm{C}-\mathrm{B}
$$


Where $\mathrm{A}$ is net revenue, $\mathrm{B}$ is the cost of feed intake during experimental period, $\mathrm{C}$ is body revenue.

\section{Statistical analysis}

Data from all response variables were subjected to a $(5 \times 2)$ factorial analysis using SAS (1996). The statistical model as factorial design was used as follows:

$$
\mathrm{Y}_{\mathrm{ijk}}=\mu+\mathrm{T}_{\mathrm{i}}+\mathrm{E}_{\mathrm{j}}+\mathrm{T}_{\mathrm{i}} \mathrm{E}_{\mathrm{j}}+\mathrm{e}_{\mathrm{ijk}}
$$

$\mathrm{Y}_{\mathrm{ijk}}$ : Observation measured , $\mu$ : Overall mean , $\mathrm{T}_{\mathrm{i}}$ : Effect of WSP $(\mathrm{i}=1, \ldots \ldots .5)$ ,$E_{j}$ : Effect of Enzymes $(j=1,2), T_{i} E_{j}$ : Effect of WSP x Enzyme interaction $\left(_{i j}=\right.$ $1, \ldots \ldots \ldots 10), \mathrm{e}_{\mathrm{ijk}}$ : Experimental error.

Significant differences among treatment means were separated using Duncan Multiple Range procedure Duncan (1955).

\section{RESULTS AND DISCUSSION}

\section{Approximate Analysis of WSP}

The same nearly chemical composition of wheat screening by-product (WSP) and yellow corn are presented in Table 2. Generally, the chemical analysis value of WSP is in agreement with those reported by Ismail (2004). The results revealed that calculated values of WSP for NDF and DE were $39.87 \%$ and $2402 \mathrm{Kcal} / \mathrm{kg}$, respectively. The chemical composition of WSP showed that it is a suitable ingredient in feeding rabbits. In this respect AbuoRaya and Galal (1971) reported that any ingredient had $70 \%$ digestible organic matter could consider as a good feedstuff for livestocks.

Table 2: Chemical composition of WSP \& YC used in the experiment as air dry basis.

\begin{tabular}{lccccccc}
\hline Items & $\begin{array}{c}\text { DM } \\
\mathbf{\%}\end{array}$ & $\begin{array}{c}\text { OM } \\
\mathbf{\%}\end{array}$ & $\begin{array}{c}\text { CP } \\
\mathbf{\%}\end{array}$ & $\begin{array}{c}\text { CF } \\
\mathbf{\%}\end{array}$ & $\begin{array}{c}\text { EE } \\
\mathbf{\%}\end{array}$ & $\begin{array}{c}\text { Ash } \\
\mathbf{\%}\end{array}$ & $\begin{array}{c}\text { NFE } \\
\mathbf{\%}\end{array}$ \\
\hline WSP & 86.25 & 76.80 & 8.53 & 16.66 & 1.35 & 15.75 & 57.71 \\
\hline YC & 87.80 & 78.30 & 8.50 & 2.20 & 4.10 & 1.56 & 83.64 \\
\hline WSP = Wheat screening by-product, $\mathrm{YC}=$ Yellow corn, & DM=Dry matter, OM=Organic \\
matter, $\mathrm{CP}=$ Crude protein, CF=Crude fiber, EE=Ether extract, NFE= Nitrogen free extract.
\end{tabular}

\section{Growth performance:}

Wheat screening by-product (WSP) effect

The data obtained in Table 3 revealed that diets containing WSP at levels of 5, 10, 15 and $20 \%$ had no significant effects on final BW, DBG and RGR compared with those of the control group. The present results are in agreement with the finding of Ismail (2004) who found that using of WSP at levels of 
$6.25,12.5,18.75$ and $25 \%$ in rabbit diets had no significant effects on BW and DBG. Also, Saki and Alipana (2005) reported that WSP at levels of 10, 20 and $30 \%$ had no significant effects on BW and DBG of broiler. Also, the present results are supported with reports of other researchers (Wold-Tsadick and Bragg, 1980 and Audren et al., 2002). Increasing the level of WSP in the rabbit diets significantly increased DFI. The highest consumed DFI was recorded for rabbits fed diet containing 20\% WSP compared with those of the control group and other treatments. For the whole experimental period, there were erratic differences in FC among dietary treatments but did not significantly differ than that of the control group. The results are in harmony with those of Saki and Alipana (2005) who reported that WSP at levels of 10, 20 and $30 \%$ had no significant effects on FC of broiler.

\section{Enzymes effect}

The data indicated that enzymes addition in rabbit diets significantly $(\mathrm{P}<0.05)$ increased final $\mathrm{BW}, \mathrm{DBG}$ and $\mathrm{RGR}$ compared with those fed diets without enzymes addition. The improvement in live BW and DBG may be due to the enhancing effect of enzymes in microflora growth in gut and cecumm, as well as, increase in volatile fatty acids production and organic matter digestibility. These results agree with the finding of Gutierrez et al. (2002) who showed that BW and DBG of rabbits were increased as a result of included Porzyme multi-enzymes and NSP digesting enzyme Xylanase and Pectinase from 25 to 39 days of age. Also, Jakic et al. (1998) indicated that BW of broiler fed diet supplemented with multi-enzymes was higher at 42 days of age as compared with the control group. Graham and Pettersson (1992) reported that dietary enzymes preparation supplemented to wheat based rations significantly improved birds DBG. The data indicated that enzymes addition in rabbits diets significantly $(\mathrm{P}<0.05)$ increased DFI compared with those fed diet without enzymes addition. These results are similar to those for Makled et al. (2005) who found that average DFI of rabbits was increased due to adding Optizyme which contains xylanase, protease, cellulase, hemocellulase and amylase at levels of 500 or $750 \mathrm{mg} / \mathrm{kg}$ feed. The results showed that enzymes addition in rabbits diets improved FC compared with those fed diet without enzymes addition. The enhancement in FC as a result of adding enzymes may be due to the effect of enzymes in improving the digestibility of nutrients as reported by El-Mandy et al.(2002). The present results of FC are in disagreement with the findings of Sarhan (2001) who found that FC was significantly improved due to optizymeenzymes supplementation for growing rabbits. 


\section{Interaction effect}

The interaction between WSP levels replacement and enzymes addition had significant effect on BW, DBG and RGR, where the highest significant $(\mathrm{P}<0.05)$ values were obtained in rabbits fed diet containing 5\% WSP with enzymes followed by those fed diet containing 10\% WSP with enzyme addition. The rabbits fed diet containing $20 \%$ WSP without enzymes recorded the lowest significant $(\mathrm{P}<0.05)$ values of final $\mathrm{BW}, \mathrm{DBG}$ and RGR compared with the other experimental groups. The interaction between levels of WSP replacement and enzymes addition had significant effect on DFI. The rabbits fed diets containing 20\% WSP provided with enzymes consumed significantly the highest DFI level while, those fed control diet consumed the least level. The best FC was recorded with rabbits fed diet containing 5\% WSP with enzymes additions followed by those fed diets containing 10, 15\% WSP and control with enzyme addition compared with the other groups.

Enzymes supplementation might improve rabbits performance by different mechanisms, for increasing DFI and improving nutrient digestibility. Both mechanisms might be induced, at least partially, by a reduction of the viscosity within the intestinal tract, reduces the viscosity of intestinal content and improves nutrients absorption (Sullivan,1987). Enzymes supplementation reduces intestinal viscosity and decrease retention time of digesta in the gut allowing for greater consumption and therefore improving FC. Also, a viscosity reduction will improve contact between nutrients and digestive enzymes leading to improve digestibility. The viability showed differences among treatment groups and it ranged between 80 and $100 \%$ (Table 3).

\section{Digestibility coefficients:}

Wheat screening by-product (WSP) effect

The results showed in Table 4 that all digestibility coefficients were significantly decreased with increasing of the WSP level in the experimental diets. These results may be due to the effect of NSP presented in the WSP in the diets of monogastric animals is an increase in viscosity of digesta and the excretion of sticky dropping. This is considered to be the main influence of NSP on productivity as reported by Salih et al. (1990), Classen and Bedford (1991), Smits and Annison (1996).

\section{Enzymes effect}

The results present in Table 4 showed that the supplementation of the enzymes to rabbits diets was significantly $(\mathrm{P}<0.05)$ improved digestibility of $\mathrm{OM}, \mathrm{CP}, \mathrm{CF}, \mathrm{EE}$ and NFE compared with those fed diets without enzymes. 
Table 4: Digestibility coefficients of rabbits fed the experimental diets

\begin{tabular}{|c|c|c|c|c|c|}
\hline Items & $\begin{array}{l}\text { Organic } \\
\text { matter }\end{array}$ & $\begin{array}{l}\text { Crude } \\
\text { protein }\end{array}$ & $\begin{array}{l}\text { Crude } \\
\text { fiber }\end{array}$ & $\begin{array}{c}\text { Ether } \\
\text { extract }\end{array}$ & $\begin{array}{c}\text { Nitrogen } \\
\text { free extract }\end{array}$ \\
\hline WSP effects, \% & $*$ & $*$ & $*$ & $*$ & $*$ \\
\hline Control & $78.94^{\mathrm{a}} \pm 1.54$ & $73.29^{a} \pm 0.87$ & $43.92^{\mathrm{a}} \pm 1.18$ & $70.66^{\mathrm{a}} \pm 3.02$ & $69.35^{\mathrm{a}} \pm 0.53$ \\
\hline $5 \%$ & $78.66^{\mathrm{ab}} \pm 1.36$ & $72.34^{\mathrm{b}} \pm 0.86$ & $43.39^{\mathrm{b}} \pm 0.86$ & $68.82^{\mathrm{b}} \pm 2.68$ & $68.87^{\mathrm{b}} \pm 0.71$ \\
\hline $10 \%$ & $78.02^{\mathrm{bc}} \pm 1.69$ & $72.11^{\mathrm{b}} \pm 1.35$ & $41.67^{\mathrm{c}} \pm 0.86$ & $68.01^{c} \pm 2.68$ & $68.42^{\mathrm{c}} \pm 1.18$ \\
\hline $15 \%$ & $77.46^{\mathrm{cd}} \pm 1.55$ & $70.01^{\mathrm{c}} \pm 0.68$ & $40.17^{\mathrm{d}} \pm 0.69$ & $67.12^{\mathrm{d}} \pm 2.64$ & $67.09^{\mathrm{d}} \pm 0.69$ \\
\hline $20 \%$ & $76.96^{\mathrm{d}} \pm 1.55$ & $68.32^{\mathrm{d}} \pm 1.02$ & $38.52^{\mathrm{e}} \pm 0.85$ & $66.11^{\mathrm{e}} \pm 2.64$ & $66.06^{\mathrm{e}} \pm 0.69$ \\
\hline Enzymes effects & $*$ & $*$ & $*$ & $*$ & $*$ \\
\hline Without enzymes & $74.95^{\mathrm{b}} \pm 0.16$ & $70.69^{b} \pm 0.17$ & $40.40^{\mathrm{b}} \pm 0.12$ & $61.62^{\mathrm{b}} \pm 0.16$ & $67.81^{\mathrm{b}} \pm 0.23$ \\
\hline With enzymes & $82.55^{\mathrm{a}} \pm 0.12$ & $74.06^{\mathrm{a}} \pm 0.28$ & $44.15^{\mathrm{a}} \pm 0.23$ & $76.33^{\mathrm{a}} \pm 0.12$ & $70.20^{\mathrm{a}} \pm 0.33$ \\
\hline Interaction effects & $*$ & $*$ & $*$ & $*$ & $*$ \\
\hline Control & $74.35^{\mathrm{d}} \pm 0.16$ & $70.69^{e} \pm 0.17$ & $40.40^{\mathrm{e}} \pm 0.12$ & $61.62^{f} \pm 0.16$ & $67.81^{\mathrm{d}} \pm 0.23$ \\
\hline Control $\mathrm{X}$ Enz. & $83.53^{\mathrm{a}} \pm 0.23$ & $75.89^{\mathrm{a}} \pm 0.17$ & $47.44^{\mathrm{a}} \pm 0.12$ & $79.70^{\mathrm{a}} \pm 0.23$ & $70.89^{\mathrm{b}} \pm 0.17$ \\
\hline $5 \%$ WSP & $74.61^{\mathrm{d}} \pm 0.21$ & $69.79^{f} \pm 0.18$ & $40.87^{\mathrm{e}} \pm 0.32$ & $60.79^{g} \pm 0.16$ & $66.77^{\mathrm{e}} \pm 0.23$ \\
\hline $5 \%$ WSP x Enz. & $82.7^{\mathrm{abc}} \pm 0.23$ & $74.89^{\mathrm{b}} \pm 0.17$ & $45.91^{\mathrm{b}} \pm 0.12$ & $76.85^{\mathrm{b}} \pm 0.23$ & $70.97^{\mathrm{b}} \pm 0.17$ \\
\hline $10 \% \mathrm{WSP}$ & $73.00^{\mathrm{e}} \pm 0.51$ & $68.06^{\mathrm{g}} \pm 0.18$ & $39.15^{\mathrm{f}} \pm 0.32$ & $59.98^{\mathrm{h}} \pm 0.16$ & $64.90^{f} \pm 0.23$ \\
\hline $10 \%$ WSP X Enz. & $83.04^{\mathrm{ab}} \pm 0.23$ & $76.15^{\mathrm{a}} \pm 0.16$ & $44.19^{c} \pm 0.12$ & $76.04^{\mathrm{c}} \pm 0.23$ & $71.94^{\mathrm{a}} \pm 0.17$ \\
\hline $15 \% \mathrm{WSP}$ & $72.92^{\mathrm{e}} \pm 0.62$ & $68.00^{\mathrm{g}} \pm 0.18$ & $38.15^{\mathrm{g}} \pm 0.32$ & $59.20^{\mathrm{i}} \pm 0.16$ & $65.05^{\mathrm{f}} \pm 0.28$ \\
\hline 15\%WSP X Enz. & $81.99^{b c} \pm 0.47$ & $72.01^{\mathrm{c}} \pm 0.16$ & $42.19^{\mathrm{d}} \pm 0.12$ & $75.03^{\mathrm{d}} \pm 0.23$ & $69.13^{\mathrm{c}} \pm 0.17$ \\
\hline $20 \% \mathrm{WSP}$ & $72.42^{\mathrm{e}} \pm 0.62$ & $65.29^{\mathrm{h}} \pm 0.17$ & $36.01^{\mathrm{h}} \pm 0.32$ & $58.19^{\mathrm{j}} \pm 0.16$ & $64.04^{\mathrm{g}} \pm 0.28$ \\
\hline $20 \%$ WSP X Enz. & $81.49^{c} \pm 0.47$ & $71.35^{\mathrm{d}} \pm 0.16$ & $41.02^{\mathrm{e}} \pm 0.12$ & $74.02^{\mathrm{e}} \pm 0.23$ & $68.08^{\mathrm{d}} \pm 0.17$ \\
\hline
\end{tabular}

\section{Interaction effect}

Rabbits fed control diet and diets containing WSP at levels of 5 and $10 \%$ with enzymes had significantly $(\mathrm{P}<0.05)$ the highest $\mathrm{OM}$ digestibility. In addition rabbits fed control diet or 10\% WSP diet with enzymes had significantly the highest $\mathrm{CP}$ digestibility. The digestibility $\mathrm{CF}$ and $\mathrm{EE}$ in rabbits fed control diet with enzymes recorded the highest contents. Rabbits fed diet containing $10 \%$ WSP with enzymes had the highest values of NFE digestibility. In general, it could be noticed that the supplementation of enzyme significantly $(\mathrm{P}<0.05)$ improved the nutrients digestibility coefficients in the all studied levels of WSP diets.

The addition of preparation enzymes which include 1-4 $\beta$-xylanase and $\alpha$-amylase activity undoubtedly enhanced the nutritive value of WSP based diets for rabbits. Also, the enzymes may improve the release of cell bound nutrients and the activity of gut ecology and nutritive values Makled et al. (2005). In addition, the improvement in digestibility coefficients of nutrients especially CF fiber may be due to the presence of 1-4 $\beta$-xylanase and $\alpha$ amylase enzymes which may improve the digestion. Parallel to our reported 
results Makled et al. (2005) found that some improvement in digestibility coefficients of most nutrients especially $\mathrm{CP}$ and $\mathrm{CF}$ with Optizyme supplementation. They also concluded that Optizyme supplementation may improve the release of cell bound nutrients, compensate for the decrease in the endogenous enzymes and improve the activity of gut ecology. The reduction in nutrient digestibility of rabbits fed all levels of WSP diets may be due to the most noticeable effect of NSPs in the diets of monogastric animals is an increase in viscosity of digesta and the excretion of sticky dropping . This is considered to be the main influence of NSPs on productivity (Salih et al., 1990, Classen and Bedford, 1991; Smits and Annison, 1996).

\section{Carcass traits:}

\section{Wheat screening by-product (WSP) effect}

Results of carcass traits are recorded in Table 5. Significant reductions were observed in carcass, dressing and giblet percentages by increasing the level of WSP in the experimental diets. Same results were mentioned by Ismail (2004) who reported that dressing percentage was significantly $(\mathrm{P}<0.05)$ affected by dietary treatments, showing gradual reduction by increasing the levels of WSP in the rabbit diets. The highest significant $(\mathrm{P}<0.05)$ values of stomach and caecum were observed with rabbits fed diet containing 20\% WSP followed by those fed 15\% WSP diet. The present results of caecum are in agreement with the finding of Ismail (2004) who found that weight of the caecum was significantly $(\mathrm{P}<0.05)$ affected by dietary treatments, being higher for the diets containing WSP than the control one.

\section{Enzymes effect}

The data revealed that rabbits fed on diet provided with enzymes recorded better significant $(\mathrm{P}<0.05)$ values of carcass, dressing, stomach and caecum compared with others fed diet without enzymes (Table 5).

\section{Interaction effect}

The interaction between WSP levels replacement and enzymes addition had a significant effect on carcass traits (Table 5). Rabbits fed diets containing different levels of WSP with enzymes addition recorded the best significant $(\mathrm{P}<0.05)$ values of carcass, dressing, stomach and caecum percentages compared with those fed WSP without enzymes. The highest significant $(\mathrm{P}<0.05)$ values of carcass and dressing percentages were recorded by rabbits fed control diet with enzymes followed by those fed diet containing $5 \%$ WSP with enzyme addition. While, rabbits fed diet containing 20\% WSP without enzymes recorded the lowest significant $(\mathrm{P}<0.05)$ values of carcass and dressing compared with those fed the other diets. The highest significant 
Table 5: Carcass traits of rabbits as affected by experimental treatments.

\begin{tabular}{|c|c|c|c|c|c|}
\hline Items & $\begin{array}{c}\text { Carcass } \\
\%\end{array}$ & $\begin{array}{c}\text { Dressing }^{1} \\
\%\end{array}$ & $\begin{array}{c}\text { Giblet }^{2} \\
\%\end{array}$ & $\begin{array}{c}\text { Stomach } \\
\%\end{array}$ & $\begin{array}{c}\text { Caecum } \\
\%\end{array}$ \\
\hline WSP effects, \% & $*$ & $*$ & $*$ & $*$ & $*$ \\
\hline Control & $56.79^{\mathrm{a}} \pm 1.22$ & $62.49^{\mathrm{a}} \pm 0.79$ & $5.76^{\mathrm{a}} \pm 0.11$ & $5.28^{\mathrm{c}} \pm 0.16$ & $6.48^{c} \pm 0.15$ \\
\hline $5 \%$ & $56.40^{\mathrm{a}} \pm 1.17$ & $62.16^{\mathrm{a}} \pm 0.83$ & $4.62^{\mathrm{b}} \pm 0.12$ & $5.61^{\mathrm{b}} \pm 0.10$ & $6.71^{\mathrm{b}} \pm 0.15$ \\
\hline $10 \%$ & $54.91^{\mathrm{ab}} \pm 1.03$ & $60.09^{\mathrm{b}} \pm 0.82$ & $4.45^{\mathrm{b}} \pm 0.10$ & $5.65^{\mathrm{b}} \pm 0.10$ & $6.83^{b} \pm 0.14$ \\
\hline $15 \%$ & $52.79^{\mathrm{b}} \pm 0.93$ & $58.73^{\mathrm{bc}} \pm 0.81$ & $4.42^{\mathrm{b}} \pm 0.10$ & $6.08^{\mathrm{a}} \pm 0.11$ & $7.34^{\mathrm{a}} \pm 0.12$ \\
\hline $20 \%$ & $52.61^{\mathrm{b}} \pm 0.96$ & $57.10^{\mathrm{c}} \pm 0.73$ & $4.36^{\mathrm{b}} \pm 0.10$ & $6.24^{\mathrm{a}} \pm 0.11$ & $7.36^{\mathrm{a}} \pm 0.08$ \\
\hline Enzymes effects & $*$ & $*$ & NS & $*$ & $*$ \\
\hline Without enzymes & $53.57^{\mathrm{b}} \pm 0.66$ & $58.68^{\mathrm{b}} \pm 0.59$ & $4.78 \pm 0.15$ & $5.55^{\mathrm{b}} \pm 0.10$ & $6.72^{b} \pm 0.11$ \\
\hline With enzymes & $55.82^{a} \pm 0.77$ & $61.55^{\mathrm{a}} \pm 0.59$ & $4.67 \pm 0.13$ & $6.01^{\mathrm{a}} \pm 0.09$ & $7.16^{\mathrm{a}} \pm 0.11$ \\
\hline Interaction effects & $*$ & $*$ & $*$ & $*$ & $*$ \\
\hline Control & $55.25^{\mathrm{ab}} \pm 1.63$ & $61.21^{\mathrm{abc}} \pm 0.87$ & $5.89^{\mathrm{a}} \pm 0.16$ & $4.97^{\mathrm{g}} \pm 0.21$ & $6.21^{\mathrm{f}} \pm 0.19$ \\
\hline Control X Enz. & $58.32^{\mathrm{a}} \pm 1.63$ & $63.76^{\mathrm{a}} \pm 1.04$ & $5.64^{\mathrm{a}} \pm 0.16$ & $5.59^{\mathrm{def}} \pm 0.11$ & $6.68^{\mathrm{def}_{ \pm 0}} \pm .19$ \\
\hline $5 \%$ WSP & $54.96^{\mathrm{ab}} \pm 1.51$ & $60.71^{\mathrm{bc}} \pm 0.87$ & $4.74^{\mathrm{b}} \pm 0.17$ & $5.42^{f} \pm 0.10$ & $6.47^{\mathrm{ef}} \pm 0.19$ \\
\hline $5 \%$ WSP x Enz. & $57.83^{\mathrm{a}} \pm 1.66$ & $63.62^{\mathrm{a}} \pm 1.04$ & $4.51^{\mathrm{b}} \pm 0.16$ & $5.81^{\mathrm{cde}} \pm 0.10$ & $6.95^{\mathrm{cde}^{\prime}} \pm 0.19$ \\
\hline $10 \%$ WSP & $53.80^{\mathrm{ab}} \pm 1.34$ & $58.65^{\mathrm{cd}} \pm 0.85$ & $4.49^{b} \pm 0.17$ & $5.45^{\mathrm{ef}} \pm 0.10$ & $6.59^{\mathrm{def}} \pm 0.17$ \\
\hline $10 \%$ WSP X Enz. & $56.02^{\mathrm{ab}} \pm 1.52$ & $61.54^{\mathrm{ab}} \pm 1.02$ & $4.42^{\mathrm{b}} \pm 0.14$ & $5.85^{\mathrm{cd}} \pm 0.10$ & $7.08^{\mathrm{bcd}} \pm 0.17$ \\
\hline $15 \% \mathrm{WSP}$ & $52.10^{\mathrm{b}} \pm 4.34$ & $57.17^{\mathrm{de}} \pm 0.85$ & $4.39^{\mathrm{b}} \pm 0.15$ & $5.87^{\mathrm{cd}} \pm 0.10$ & $7.08^{\mathrm{cd}} \pm 0.09$ \\
\hline $15 \%$ WSP $x$ Enz. & $53.48^{\mathrm{ab}} \pm 1.34$ & $60.29^{\mathrm{bc}} \pm 0.85$ & $4.48^{\mathrm{b}} \pm 0.16$ & $6.30^{\mathrm{ab}} \pm 0.11$ & $7.61^{\mathrm{a}} \pm 0.11$ \\
\hline $20 \% \mathrm{WSP}$ & $51.76^{\mathrm{b}} \pm 1.36$ & $55.67^{\mathrm{e}} \pm 0.85$ & $4.39^{\mathrm{b}} \pm 0.13$ & $6.03^{\mathrm{bc}} \pm 0.11$ & $7.27^{\mathrm{bc}} \pm 0.12$ \\
\hline 20\%WSP X Enz. & $53.47^{\mathrm{ab}} \pm 1.40$ & $58.53^{\mathrm{cd}} \pm 0.64$ & $4.34^{\mathrm{b}} \pm 0.17$ & $6.46^{\mathrm{a}} \pm 0.11$ & $7.46^{\mathrm{ab}} \pm 0.09$ \\
\hline
\end{tabular}

Means having different letters at the same column within each factor are differ significantly.

$*=(\mathrm{P}<0.05), \quad \mathrm{NS}=$ Not significant.

1-Dressing \% $=($ Carcass weight + Giblets $/$ Live body weight $) \times 100$.

2- Giblets $=$ Heart + Liver + Kidneys, $\quad \mathrm{WSP}=$ Wheat screening by-product .

Enz.=Enzymes (1-4 $\beta$-xylanase and $\alpha$-amylase)

$(\mathrm{P}<0.05)$ values of giblet, stomach and caecum percentages were recorded by rabbits fed control diet followed by those fed diets containing 20 and $15 \%$ WSP with enzyme addition (Table 5).

\section{Blood constituents:}

\section{Wheat screening by-product (WSP) effect}

Results of total protein, albumin, globulin, cholesterol, AST, ALT and urea are recorded in Table 6. Significant reductions were detected in total protein, cholesterol and urea by increasing the level of WSP in the experimental diets.

\section{Enzymes effect}

The data in Table 6 revealed that diets provided with enzymes had no significant effect on total protein, albumin, globulin and urea compared with diets without enzymes. Results regarding albumin and globulin are in agreement with those reported by Veselin et al. (2003) who found no significant changes in the albumin and globulin levels in the blood of rabbits 
fed concentrate mixture diets supplemented with Protozin multi-enzymes (19 $\mathrm{mg} / \mathrm{kg}$ diet). However, rabbits fed on diet provided with enzymes had significant decrease in its plasma total cholesterol compared with those fed diet without enzymes. These results are in disagreement with results reported by Attia et al. (2001a \& b), and Shakmak (2003) who mentioned that Avizyme product which contains xylanase, $\alpha$-amylase and protease had no effect on the plasma total cholesterol level. Also Zeweil et al. (2005) reported that enzymes (xylanase, $\alpha$-amylase and protease) had no significant effect on Japanese quail plasma cholesterol levels. Abou El-Wafa et al. (2002) reported that there was a significant increase in plasma total cholesterol with the addition of Avizyme, (1 Kg/ton) to corn-soy broiler diet.

Moreover, the supplementation of enzymes to rabbit diets significantly decreased blood AST and ALT concentration than those fed diets without enzymes supplementation. addition of enzymes improved the liver functions AST and ALT. These results are in agreement with those of Abd El-Fattah et al. (2003) and Ibrahim and Saleh (2005). On the other hand El-Gendi et al. (2000) found that chicks fed Kemzyme had the highest average of ALT (7.51 $\mathrm{u} / \mathrm{l})$. However, these results are not consistent with the findings of Salem et al. (2008) who reported that Avizyme supplementation had no significant effect on plasma AST concentration. Kemzyme did not significantly affect plasma AST concentration. Also when Avizyme and Kemzyme were added together, plasma AST concentration was not significantly affected.

\section{Interaction effect}

The interaction between WSP levels replacement and enzymes supplementation had a significant effect on total protein, cholesterol and urea (Table 6). However, the differences between rabbits fed all levels of WSP with or without enzymes and the control diet in albumin and globulin were not significant. The data revealed that rabbits fed diets containing different levels of WSP and provided with enzymes recorded the lowest significant $(\mathrm{P}<0.05)$ values of plasma cholesterol compared with those fed diets containing WSP without enzymes and control diet. The present results of blood parameters fell within the physiological normal values for rabbits as reported by Abd ElKhalek et al. (2000) and Ashour (2001). These values may indicate the possibility of incorporation of different levels of WSB in diets of rabbits without adverse effects on protein and cholesterol metabolism.

However, the interaction between WSP levels replacement and enzymes supplementation had a significant effect on AST and ALT concentration. Rabbits fed diets containing different levels of WSP and provided with enzymes recorded the lowest significant $(\mathrm{P}<0.05)$ values of AST and ALT compared with those fed the WSP diets without enzymes or the 
control diet. Also, data in Table 6 revealed that better values of both AST and ALT were recorded for rabbits fed diets containing WSP with enzymes supplementation compared with those fed diets containing WSP without enzymes or control diet (Table 6).

\section{Chemical composition of meat:}

Results in Table 7 represent the chemical composition of meat rabbits as affected by the WSP replacement with or without enzymes in diets. The comparison among the experimental groups showed that rabbit meats had nearly similar contents of dry matter, protein, ether extract and ash for all experimental groups. These findings clearly showed the absence of any significant differences in the chemical composition of rabbits meat due to the effect of dietary treatments. The present results are in accordance with those reported by Ismail and Gippert (1999) and Abd El-Khalek et al. (2000) who reported insignificant differences in the chemical composition of NZW rabbit meat due to the effect of dietary treatments.

Table 7: Meat composition of growing rabbits as affected by different experimental treatments

\begin{tabular}{|c|c|c|c|c|}
\hline \multirow[b]{2}{*}{ Items } & \multicolumn{4}{|c|}{ Meat composition (\%) } \\
\hline & $\begin{array}{c}\text { Dry } \\
\text { matter }\end{array}$ & $\begin{array}{l}\text { Crude } \\
\text { protein }\end{array}$ & $\begin{array}{c}\text { Ether } \\
\text { extract }\end{array}$ & Ash \\
\hline WSP effect, \% & & & & \\
\hline $\begin{array}{l}0 \text { (Control) } \\
5 \% \\
10 \% \\
15 \% \\
20 \% \\
\end{array}$ & $\begin{array}{l}28.23 \pm 0.22 \\
27.97 \pm 0.21 \\
27.86 \pm 0.19 \\
28.99 \pm 0.21 \\
28.19 \pm 0.18 \\
\end{array}$ & $\begin{array}{l}20.67 \pm 0.18 \\
20.42 \pm 0.16 \\
20.49 \pm 0.18 \\
20.32 \pm 0.16 \\
20.59 \pm 0.27 \\
\end{array}$ & $\begin{array}{l}4.24 \pm 0.03 \\
4.01 \pm 0.02 \\
4.05 \pm 0.04 \\
4.26 \pm 0.04 \\
4.18 \pm 0.03 \\
\end{array}$ & $\begin{array}{l}3.43 \pm 0.03 \\
3.53 \pm 0.04 \\
3.30 \pm 0.05 \\
3.43 \pm 0.02 \\
3.39 \pm 0.02 \\
\end{array}$ \\
\hline $\begin{array}{l}\text { Enzymes effects } \\
\text { Without enzymes } \\
\text { With enzymes }\end{array}$ & $\begin{array}{l}28.18 \pm 0.20 \\
28.24 \pm 0.18\end{array}$ & $\begin{array}{l}20.47 \pm 0.26 \\
20.67 \pm 0.23\end{array}$ & $\begin{array}{l}4.26 \pm 0.04 \\
4.12 \pm 0.08\end{array}$ & $\begin{array}{l}3.38 \pm 0.02 \\
3.46 \pm 0.06 \\
\end{array}$ \\
\hline $\begin{array}{l}\text { Interaction effects } \\
0(\text { Control) } \\
0 \text { (Control) x Enz. } \\
5 \% \text { WSP } \\
5 \% \text { WSP x Enz. } \\
10 \% \text { WSP } \\
10 \% \text { WSP x Enz. } \\
15 \% \text { WSP } \\
15 \% \text { WSP x Enz. } \\
20 \% \text { WSP } \\
20 \% \text { WSP x Enz. }\end{array}$ & $\begin{array}{l}28.10 \pm 0.21 \\
28.54 \pm 0.11 \\
27.66 \pm 0.15 \\
28.24 \pm 0.17 \\
27.66 \pm 0.21 \\
27.97 \pm 0.23 \\
27.75 \pm 0.19 \\
28.23 \pm 0.21 \\
28.10 \pm 0.16 \\
28.20 \pm 0.24\end{array}$ & $\begin{array}{l}20.47 \pm 0.26 \\
20.87 \pm 0.26 \\
20.19 \pm 0.02 \\
20.66 \pm 0.28 \\
20.33 \pm 0.23 \\
20.66 \pm 0.27 \\
20.08 \pm 0.01 \\
20.57 \pm 0.29 \\
20.57 \pm 0.31 \\
20.62 \pm 0.49\end{array}$ & $\begin{array}{l}4.26 \pm 0.04 \\
4.22 \pm 0.04 \\
4.02 \pm 0.04 \\
4.00 \pm 0.04 \\
4.09 \pm 0.04 \\
4.00 \pm 0.06 \\
4.30 \pm 0.04 \\
4.22 \pm 0.06 \\
4.20 \pm 0.04 \\
4.15 \pm 0.04\end{array}$ & $\begin{array}{l}3.38 \pm 0.02 \\
3.48 \pm 0.03 \\
3.47 \pm 0.07 \\
3.59 \pm 0.03 \\
3.27 \pm 0.07 \\
3.32 \pm 0.07 \\
3.39 \pm 0.02 \\
3.45 \pm 0.02 \\
3.34 \pm 0.02 \\
3.44 \pm 0.02\end{array}$ \\
\hline
\end{tabular}




\section{Economic efficiency:}

The effect of dietary WSP replacement with or without enzymes on of both of E.E.F and R.E.E.F are presented in Table 8. During the whole experimental period, rabbits fed diet containing 5\% WSP with enzyme showed higher net revenue, E.E.F and R.E.E.F(\%) followed by those fed diets containing control, 10\% WSP and $15 \%$ WSP with enzymes than other experimental groups. The increasing in body weight gain as a result of providing rabbits with enzymes reduced the total cost of DBG of these rabbits as compared with those fed diets without enzymes supplementation in diets.

Table 8. Economical efficiency (E.E.F) and relative economical efficiency (R.E.E.F) of rabbits as affected by experimental treatments

\begin{tabular}{lccccccc}
\hline $\begin{array}{l}\text { Treatment } \\
\text { groups }\end{array}$ & B.W.G & F.I & $\begin{array}{c}\text { Price } \\
\mathbf{k g} / \mathbf{F e e d} \\
(\mathbf{p . t})\end{array}$ & $\begin{array}{c}\text { Feed } \\
\mathbf{c o s t} \\
(\mathbf{L . E .})\end{array}$ & $\begin{array}{c}\text { Net } \\
\text { Reven. } \\
(\mathbf{L . E})\end{array}$ & E.E.F & R.E.E.F \\
\hline Control & 1175.00 & 4817.09 & 162.56 & 7.831 & 21.150 & 2.701 & 100.0 \\
Control X Enz. & 1287.90 & 4978.25 & 166.06 & 8.267 & 23.182 & 2.804 & 103.8 \\
5 \%WSP & 1164.50 & 4970.17 & 163.10 & 8.106 & 20.961 & 2.586 & 95.7 \\
5 \%WSP x Enz. & 1367.10 & 5156.12 & 166.60 & 8.590 & 24.608 & 2.865 & 106.1 \\
10\%WSP & 1150.80 & 5086.59 & 163.20 & 8.301 & 20.714 & 2.495 & 92.4 \\
10\%WSP x Enz. & 1356.50 & 5247.70 & 166.70 & 8.748 & 24.417 & 2.791 & 103.3 \\
15\%WSP & 1131.50 & 5219.82 & 161.76 & 8.444 & 20.367 & 2.412 & 89.3 \\
15\%WSP x Enz. & 1333.00 & 5248.68 & 165.26 & 8.674 & 23.994 & 2.766 & 102.4 \\
20\%WSP & 1121.90 & 5371.53 & 159.60 & 8.573 & 20.194 & 2.356 & 87.2 \\
20\%WSP x Enz. & 1316.70 & 5548.17 & 163.10 & 9.049 & 23.701 & 2.619 & 97.0 \\
\hline
\end{tabular}

Price of kg live body weight was 18.0 L.E, Price of kg Xylam was 70.0 L.E at experimental period.

Net revenue $=$ body revenue - feed cost. $\quad *$ E.E.F $=($ Net revenue $/$ feed cost $)$.

R.E.E.F, assuming control treatment $=100 \%$, Enz. $=$ Enzymes $(1-4 \beta$-xylanase and $\alpha$-amylase $)$ WSP= Wheat screening by-product.

In general, it could be noticed that all dietary treatments achieved profit hence the greatest profit calculated for rabbits fed 5\% WSP containing diet and provided with enzyme among the enzymatic treatments. The obtained results is inagreement with finding by Sarhan (2001) who found that E.E.F improved during the period from 3 to 10 and from 10 to 12 weeks of age due to optizyme supplementation in rabbits diet. Makled et al. (2005) indicated that E.E.F of rabbits was improved during the period from 8-10 and from 1012 weeks of age by adding 500 or 750 optizyme / $\mathrm{kg}$ feed in supplemented groups compared with the un-supplemented one. This may be related to the price reduction of the WSP containing diets. Generally, the use of agricultural by-products in rabbit diets has been resulted in high E.E.F and R.E.E.F, as supported by Ismail and Gippert (1999).

Conclusively, it could be concluded that the present results showed that use of WSP can be successfully fed at level $5 \%$ of growing rabbits diet 
supplemented with enzymes (xylanase and amylase) without any adverse effect on growing rabbits performance and economical efficiency, under Egyptian conditions.

\section{ACKNOWLEDGMENT}

This work was carried out through project funded by Council of Agricultural Research and Development.

\section{REFERENCES}

A.O.A.C. (2000). Official Methods of Analysis. Sixteenth Edition. Association of Official Analytical Chemist, Washington, D. C, USA.

Abd El-Fattah, S.A; El-Hommosany, Y.M. and Maie, Ali, F.M. (2003). Response of quail chicks to diet quantitative immunological and physiological aspects. Egypt. Poult. Sci., 23: 421- 440.

Abd El-Khalek, A.E.; Abd El-Ghani, A.1.; El-Ayouty, S.A. and Shatifa, M.A. (2000). Some blood constituents and characteristics of gastrointestinal tract in rabbits as affected by feeding silage. Egyptian J. Anim. Prod., 37: 1-13.

Abou El-Wafa, S. A.; Osman, A.G.; Abd Allah and Hataba, N.A. (2002). Evalution of some commercial enzymes in broiler diets based on corn or barley/soy in combination with growth promoter. Egypt. Poult. Sci., 22: 10231045.

Abou-Raya, A.K. and Galal, A.Ch. (1971). Evaluation of poultry feeds in digestion trials with reference to some factores involved, A.R.E.J. Anim. Prod., 11: 207221.

Adams, C. A. and Pough, R. (1993). Non-starch polysaccharides digestion in poultry. Feed Compounder, 13:19-21.

Ashour, G. (2001). Blood metabolites, minezals and hormones in relation to growing rabbits. Egyptian J. Rabb., 11: 73-91.

Attia, Y.A.; Abd EI-Rahman, S.A. and Qota, E.M.A. (2001a). Effects of microbial phytase without or with cell wall splitting enzymes on the performance of broilers fed marginal levels of dietary protein and metabolizable energy. Egypt. Poult. Sci., 21: 512-547.

Attia, Y.A.; Abd EI-Rahman, S.A.; and Kies, A.K. (2001b). Utilization of vegetable diets containing different levels of rice bran with or without commercial enzymes in Norfa laying hen diets. J.Agric. Sci. Mansoura Univ., 26: 3557-3577.

Audren, G.P.; Calssen, H.L.; Schwean, K.V. and Raca, V. (2002). Nutrional value of wheat screening of broiler chickens. J. Anim. Sci., 82. 393-398.

Bedford, M . R. and Morgen A. J. (1996). The use of enzymes in poultry diet. World's Poult. Sci. J ., 52: $61-68$.

Campbell, G. L. and Bedford, M.R. (1992). Enzyme application for monogastric feeds. A review.Can. J. Anim. Sci., 72: 449-466.

Chesson, A. (1993). Feed enzymes. Anim. Feed Sci. Technol., 45: 65-79. 
Classen , H. L. and Bdeford, M. R. (1991). The use of enzyme to improve the nutritive value of poultry feeds . In. Recent Advances in Animal Nutrition, W. Haresing and D. J. A. Cole , Eds , Butterworth , London, England , PP. 95 - 115.

Cowieson, A.J.; Hruby, M. and Faurschou Isaksen, M. (2005). The effect of conditioning temperature and exogenous xylanase addition on the viscosity of wheatbased diets and the performance of broiler chickens. British Poult.Sci. 46:717-724.

Doumas, B.T.; Watson, W.A. and Biggs, H.G. (1971). Determination of serum albumin. J. Chem. Acta., 31: 87-89.

Duncan, D. B. (1955). Multiple range and multiple F test. Biometrics, 11:1-42.

Easter, R.A. (1988). Biochemical aids in gastro-intestinal development and functions in biotechnology in feed industry. Edited by T.P. Lyons. Proceeding of all tech. animal symposium. Alltech. Technical publications, Kentucky, USA.

El-Gendi, G.M.; Soliman, A.F. and Habib, A.G. (2000). Evaluating four feed additives for improving productive and metabolic performance of broiler chicks. Egypt. Poult. Sci., 20: 103-122.

El-Mandy, M.R.; Salem, F. A. and EL-Homeland, Y.M. (2002). Effect of kemzyme in rabbit ration differing in their protein levels on digestion, blood constituentas and carcass Traits , 3 rd conf. on rabbit prod., in Hot climates , Hurghada (Egypt ), 495 - 505.

Feed Composition Tables for Animal and Poultry Feedstuffs Used In Egypt (2001). Technical bulletin No.1, central lab for Feed and food; Ministry of Agriculture, Egypt.

Ferket, P.R. (2011) Nutrition-disease interactions regarding gut health in chickens. 18th European Symposium on Poultry Nutrition, Izmir, Turkey. 200 - 212.

Fonnesbeck, P.V. ; Harris, L.E. and Kearl, L.C. (1974). Digestion of plant cell walls by animals. J. Anim. Sci., 39:182-188.

Gornal A. C; Bardawill, C.J. and David, M.M. (1949). Determination of serum protein by means of biuret reaction. J. Biol. Chem., 177,751.

Graham, H. and Pettersson, D. (1992). A note on the effect of a $\beta$-glucanase in broiler chicks fed a barley based diet. Sweedish J. Agri. Res. 22:39-42.

Gutierrez, I.; Espinosa , A.; Garcia, J.; Carabano, R. and Dgblas, J. C. (2002). Effects of strach and protein sources, heat processing, and exogenous enzymes in starter diets for early weaned rabbits. Anim. Feed sci, and technol., 98:175 186.

Ibrahim, K.A. and Saleh, E.S. (2005). Response of male broiler chicks to skip a day feeding Programs. Egypt. Poult. Sci., 25:351-37.

Ismail, F. S. A. (2004). Wheat screening by-product in- growing rabbit diets. Egyptian J. Rabbit Sci., 14: 65-79.

Ismail, F.S.A. and Gippert, T. (1999). Using sunflower by-product in growing rabbit diets. Egyptian J. Rabbit Sci., 9: 285-294.

Jakic, D.; Romanic, S.; Bukovski, M.; Tadic, D. and Rajic, I. (1998). Influence of Protozin in live weight gain and feed conversion in broilers. Zivnarstvo, 33: 261266 
Jiang, Z.; Lu, Y.; Zhou, F.; Han, Z. and Wang, T. (2008). Effects of different levels of supplementary alpha-amylase on digestive activities and pancreatic amylase mRNA expression of young broilers. Asian-Australian J. Anim. Sci., 21:97-102.

Makled, M. N.; Metwally, M. A.; Soliman, I. A. and younis, H. A. (2005). Impact of different levels of dietary multienzymes supplement on california rabbit performance 3rd . International Poultry Conference, 4 - 7 Apr . 2005 Hunghada - Egypt .

Michael, A.E. (2002). Enzyme use in commercial layer production. Multi-State Poultry Meeting, May 14-16.

NRC (National Research Council) (1994). Nutrient Requirements of Rabbits. 9th Edition, National Academy Press, Washington, D.C.

Odetallah, NH. (2000). The use of dietary enzymes to alleviate enteric disorders of turkeys. Ph.D. Thesis, North Carolina State University, 197 pp.

Pagano Toscano, G.; Benatti, G and Zoccarato, I. (1986). Comparison of crude fiberand the Van Soest detergent methods for fiber determination in rabbit feeds. J. Appl. Rabbit Res., 9:69-75.

Pérez-Vendrella A. M.; Angulo E.; and Barberàa, J. B. (2009) Presence of xylanaseinhibitors in different cereals and their by- products. XIIIth European Poultry Conference Tours, France.

Saki, A.A. and Alipana, A. (2005). Effect of Dietary Wheat Screening Diet on Broiler Performance, Intestinal Viscosity and Ileal Protein Digestibility, International Journal of Poultry Science 4: 16-20.

Salem, A.A.; El-Anwer, E.M.; Abo-Eita, M. and Namra, M.M.M. (2008). Productive and physiological performance of golden montazah male chickens as affected by feed restriction and Avizyme supplementation. Egyptian Poultry Sci., 28: 1137-1164.

Salih, M. E.; Classen, H. L. and Compbell, G.L. (1990). Response of chickens fed on hull less barely to dietry $\beta$ - glucanase at different ages. J. Anim Sci. Technol. 33:139 - 149.

Sarhan, A. (2001). Effect of protein level and supplementation on enzyme preparation in diets of growing rabbits. Egyptian J. Nut and Feeds, 4: 832 - 843.

SAS (1996). SAS Procedure Guide. Version 6.12 Edition. SAS Institute INC., Cary, NC, USA. sativa (Haw.). Celak. J. Ethnopharm, 73: 445-451.

Selim, N.A.; Abd El-Hakim, A.E.S.; Radwan, A.M. and Shalash, S.M. (2009). New Modulation in Early Nutrition for Broiler Chicks Fed: 1- Low Protein Diets. XIIIth European Poultry Conference Tours, France.

Shakmak, S. (2003). Improvement of productive performance in poultry. M. Sc. Thesis, Mansoura University. Egypt.

Smits, C. H. M. and Annison, G. (1996). Non-Starch polysaccharides in broiler nutrition . towards a physiologically valid approach to their determination . World's Poult. Sci. Journal, 52: 203 - 221.

Sullivan, L.M. (1987). Evaluation of sorghum varieties in poultry diets. Feed Facts. Published by grain sorghum producers. Association, Vol. 4, No. 2. 
Tawfeek, M. I. (1996). Effect of feeding system and supplemented diet with kemzyme on growth, blood constitvents, carcass traits and reproductive performance in rabbits under intensive production conditions. Egyptian J. Rabbit Sc., 6:21-37.

Veselin Radev; Kina sivkova and Encho Enev (2003). Changes in Hematological parameters of rabbits given multi-enzyme Protozin in the diet. Trakia Journal of Sci., $1: 67-71$.

Walsh, G.A.; Power, R. F. and Headon, D. R. (1993). Enzymes in the animal-feed industry. Tibtech., 11: 424-429.

Wold- Tsadick, M.S. and Bragg, D.B. (1980). Utilization of wheat screening in the broiler diet as a major source of energy. Poult. Sci., 56: 1674 (Abstract).

Zeweil, H.S.; EI-Genedy, Salwa and Isshak, N.S. (2005). Effect of rice bran and enzyme mixture supplementation on performance, digestibility and carcass traits of growing Japanese quail. Egypt. Poult. Sci., 25: 225-240.

Zollner, N. and Kirsch, K. (1962). Cited from Z. Ges. Exp. Med., 135: 545.

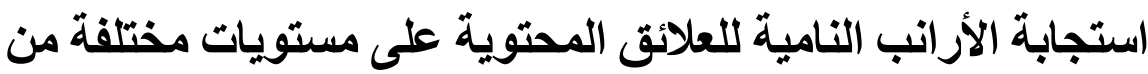
مخلفات غربلة القمح مع أو بلون الضونة إضافة الإنزيمات ماتوبات

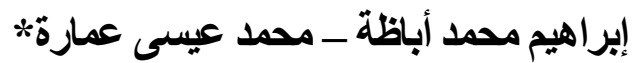

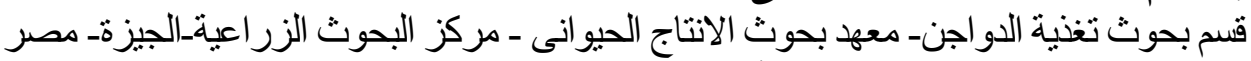

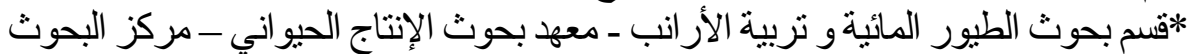

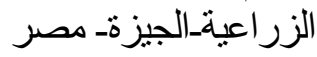

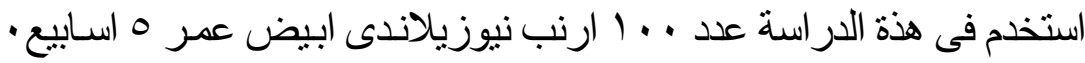

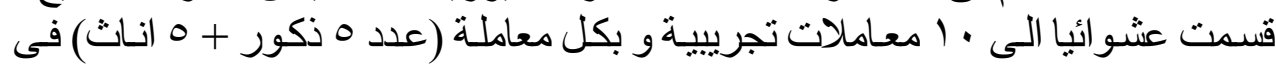

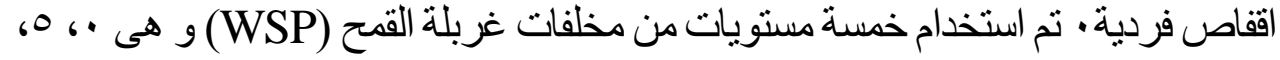

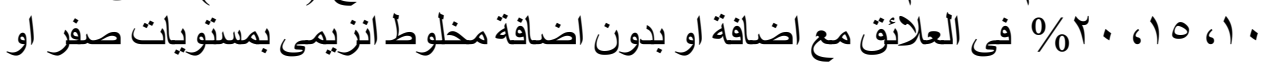

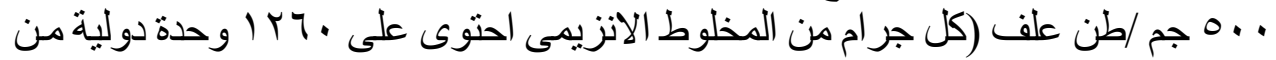

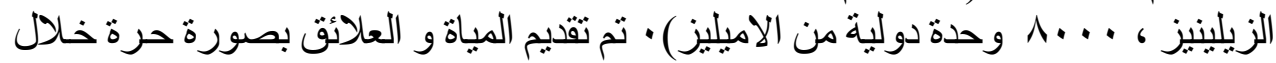

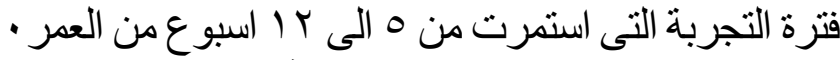

$$
\begin{aligned}
& \text { تتلخص التتائج المتحصل عليها فيما يلى هن: }
\end{aligned}
$$

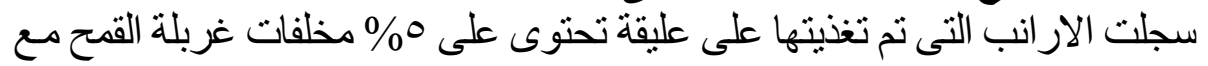

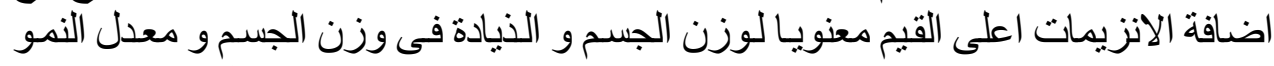

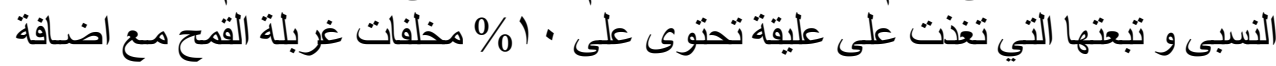

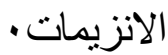




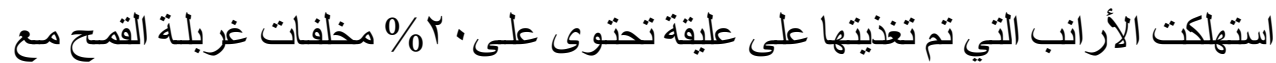
اضافة الانزيمات اعلى كمية استهلاكك للعلف بالمقارنة بالتى تم تغنيتها على على عليقة المقارنة و

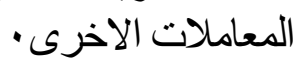

سجلت الأر انب التي تم تخذيتها على عليقة تحتوى على ٪ \% مخلفات غربلة القمح مع اضافة

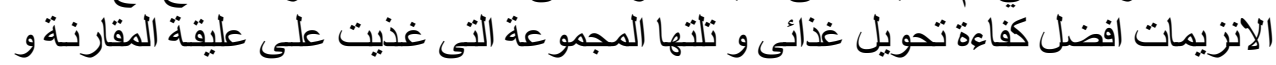

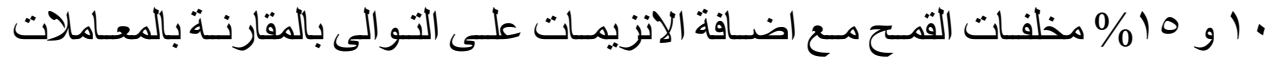
الاخرى · الافو

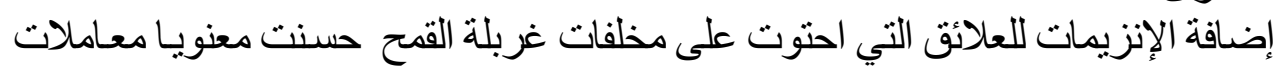

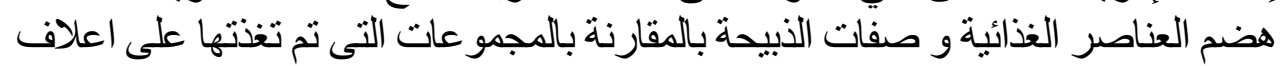
بدون اضافة انزيمات

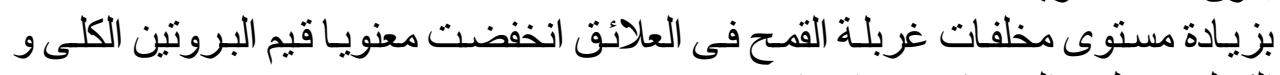
الكوليسترول و اليوريا في دم الار انب.

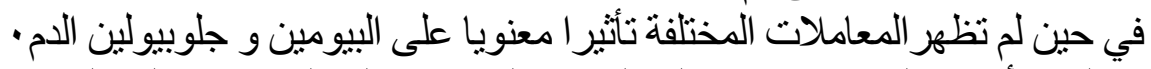

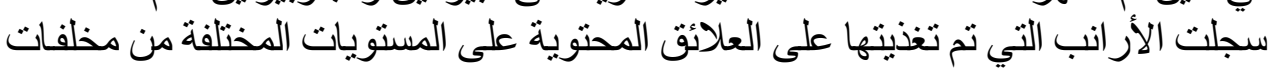

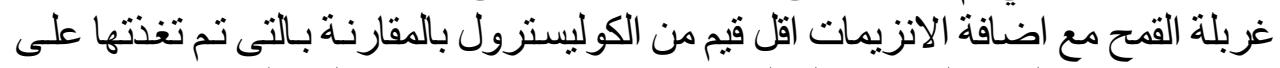

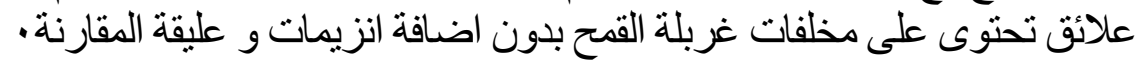

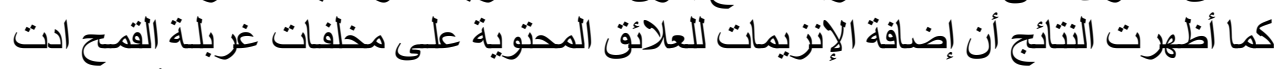

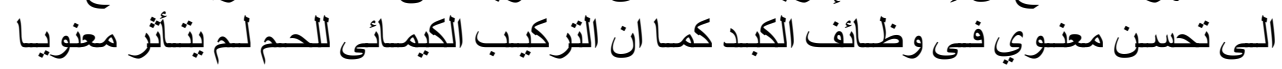

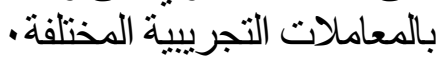

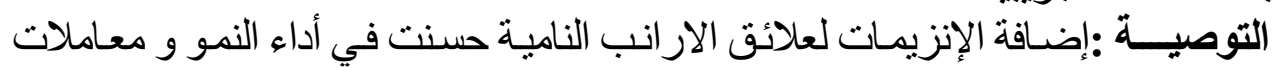

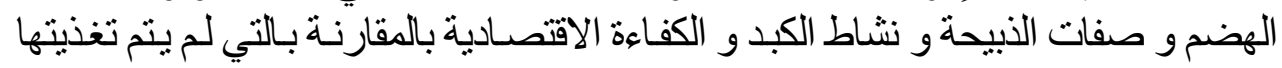

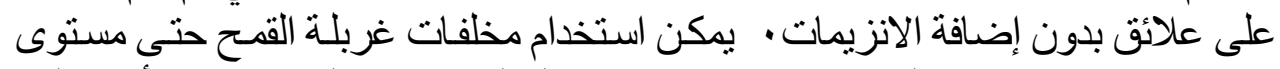

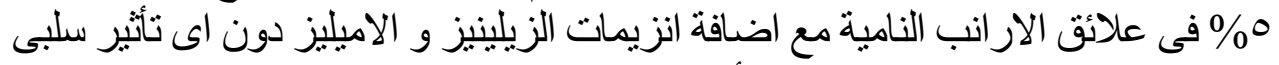
على اداء النمو و الكفاءة الاقتصادية للأر انب النامية النامية. 